\title{
Educational pathways and dropout from higher education in Germany
}

Sophie Müller, University of Bamberg, Germany

sophie.mueller@uni-bamberg.de

Thorsten Schneider, University of Leipzig, Germany

(Received June 2013 Revised August 2013)

doi:10.14301/Ilcs.v4i3.251

\section{Abstract}

Extending access to higher education has led to a growing heterogeneity in the social origins and previous educational biographies of first-year students. They differ in their socialization, their preparedness for tertiary studies, and the salience of alternative options. How do these differences relate to social inequality in dropout from higher education? Drawing on theories and concepts of rational choice, differential learning environments, and selection, we argue that social origins and pre-tertiary educational pathways have at least an initial impact on dropout risks. We draw on retrospective life course data from the "Adult Education and Life-Long Learning" stage of the German National Educational Panel Study (NEPS) to use pre-tertiary pathways to reconstruct educational careers and perform an event history analysis on dropping out of higher education. Results suggest that these pathways substantially influence dropout rates in Germany. Students taking the direct pathway via the Gymnasium (i.e. the school type representing the highest school track) have significantly lower dropout rates than students with an upwardly mobile educational biography or students who obtained a vocational qualification before starting higher education. Whereas students from a higher social background are less prone to drop out than students from a lower social background at universities, social origins do not have any significant direct influence on dropout rates at universities of applied sciences and influence only the likelihood of entering these institutions.

Keywords: dropout, higher education, tertiary education, event history analysis, educational pathways, social origin

\section{Introduction}

Sociological studies exploring the mechanisms of dropout from tertiary education are rather scarce in Europe in general and Germany in particular. However, research in this field is important, because dropping out relates to issues of social inequality and influences how far graduation rates will increase in the population.

In times of accelerated technological change, modern societies respond to economic competition by increasing the proportion of higher education graduates. They pursue this goal by opening up access to higher education to a larger proportion of the population, and by fostering permeability from secondary and post-secondary education into tertiary education. However, due to their different qualifications and prerequisites, these newlyentitled groups might face higher obstacles to obtaining a higher education degree.

In this context, Germany is a particularly interesting case. Graduation rates at tertiary level 
are far below the OECD average (OECD, 2012, p. 68) and have increased more slowly than in other countries due to institutional barriers (Powell \& Solga, 2011). In addition, Germany has very high social inequality in access to tertiary education (Hillmert \& Jacob, 2010). Therefore, providing new paths to obtain a higher education entrance certificate is an important step in raising tertiary completion rates. Some attempts have been made to provide new educational options which afford eligibility to higher education. However, the persistently high segregation of the German education system, particularly the "schism in education" (Baethge, 2010, p. 281) between vocational and general education, might render it particularly difficult for those who entered higher education via nonstandard pathways to complete it successfully.

In this article, we want to gain insights into the mechanisms of dropout from a life-course perspective using recent longitudinal nationwide data from Germany. The main research questions are: Do previous secondary or post-secondary educational pathways and social origins influence dropping out of higher education? Do these influences differ by type of higher education institution? And do these features become less important as the length of study time increases?

\section{The German education system}

The German education system is characterized by early tracking, high differentiation, and high stratification (Allmendinger, 1989). The lower secondary level differentiates between three tracks. In most federal states, each of these three tracks has been represented for many years by one specific school type: the lower track by the Hauptschule, the intermediate track by the Realschule, and the upper, academic track by the Gymnasium. The Hauptschule provides basic general education and usually covers Grades 5 to 9 (sometimes also including Grade 10). At the Realschule, students receive more extensive general education. This school type usually covers Grades 5 to 10. The Gymnasium aims to teach intensified general education and comprises Grades 5 to 12 or 13. The Gymnasium is the only one of the three school types offering students a final examination, known as Abitur, entitling them to enter higher education. Some federal states provide the lower and intermediate track within one school type; others also offer comprehensive schools containing all three tracks. However, comprehensive schools have not replaced the traditional Gymnasium in any single federal state.

High-achieving students from the Haupt- or Realschule who want to gain eligibility to higher education can transfer to a Gymnasium or to other schools offering senior classes (gymnasiale Oberstufe) at the upper secondary level. Some of these schools allow for part-time schooling, offer (either exclusively or additionally) restricted forms of the higher education entrance certificate, or also award vocational qualifications. A further possibility is to enter higher education without a higher education entrance certificate via a special examination (Begabtenprüfung), for talented or vocationally qualified persons. However, between 1995 and 2010, only about 1 per cent of students accessed higher education on this path (Autorengruppe Bildungsberichterstattung, 2012, p. 118, Tab. F1-4A).

There has been a considerable expansion of tertiary education in Germany in recent decades. For example, the proportion of 18- to 21-year-old students entering tertiary education increased from 17 per cent in 1980 to 44 per cent in 2009 (Statistisches Bundesamt, 2012). However, expansion in tertiary education has not been as extensive as that in secondary education (Lörz \& Schindler, 2009, p. 98). Moreover, Germany has lower proportions of participation and graduation in tertiary education, and has experienced a smaller increase in tertiary enrolment and completion since the 1980s, than a number of other European countries (Arum, Gamoran, \& Shavit, 2007; Powell \& Solga, 2011; OECD, 2012, p. 68). Although inequality in completing secondary education decreased during the period of educational expansion, social inequality in post-secondary decisions increased (Mayer, Müller, \& Pollak, 2007). Given the same level of achievement, students with Abitur from a higher social background more often access university directly, whereas students from the middle and lower classes more often opt for the less risky strategy of vocational training first and studies afterwards, or they even decide against higher education studies despite their eligibility (Becker \& Hecken, 2009; Hillmert \& Jacob, 2003; Mayer et al., 2007; Müller \& Pollak, 2004; Reimer \& Pollak, 2010). Those who have decided to take up higher education studies differ in their educational biography depending on their social origins. Higher 
social classes follow the standard sequence from primary school to Gymnasium to university significantly more often (Jacob \& Weiss, 2010).

The decision to enter higher education involves options in itself. The higher education system in Germany is binary (Mayer et al., 2007). On the one hand, there are the more practically oriented universities of applied sciences (Fachhochschulen) offering shorter and more structured study programmes of about 3.5 years. On the other hand, there are the more theory-oriented universities with longer study programmes of 5 to 6 years. Whereas students from a higher social background are more likely to enrol at a university, students from a lower social background are more likely to opt for a university of applied sciences. The degrees awarded by the different institutions are also connected to unequal chances. Graduates from the universities of applied sciences face more restrictions in accessing postgraduate studies, and their labour market outcomes are also less favourable (Müller, Brauns \& Steinmann, 2002) .

To provide information on the prevalence and social selectivity of different educational pathways, we developed a basic classification of these pathways, which is also used later in our main analysis. This classification was based on first, whether students attended Gymnasium from the lower secondary level; second, whether they completed vocational education and training and third, whether they took up tertiary studies and, if so, whether they attended university $(U)$ or university of applied sciences (UAS; see Table 1). If individuals completed vocational training and started tertiary studies, only vocational qualifications before tertiary studies are taken into account, while vocational qualifications acquired after tertiary studies are discounted.

\section{Table 1. Types of educational pathways}

\begin{tabular}{lccc} 
Pathway & $\begin{array}{l}\text { Gymnasium at lower } \\
\text { secondary level }\end{array}$ & $\begin{array}{l}\text { Completed vocational } \\
\text { and educational } \\
\text { training }\end{array}$ & $\begin{array}{l}\text { Tertiary education at } \mathbf{U}= \\
\text { university, UAS = university } \\
\text { of applied sciences }\end{array}$ \\
\hline $1 a$ & $x$ & & $U$ \\
$1 b$ & $x$ & UAS \\
$1 c$ & $x$ & $x$ & - \\
\hline $2 a$ & $x$ & $x$ & $U$ \\
$2 b$ & $x$ & $x$ & UAS \\
$2 c$ & $x$ & & - \\
\hline $3 a$ & & & $U$ \\
$3 b$ & & & UAS \\
$3 c$ & & $x$ & - \\
\hline $4 a$ & & $x$ & $U$ \\
$4 b$ & & $x$ & UAS \\
$4 c$ & & & - \\
\hline
\end{tabular}

Table 2 gives an overview of the frequency of these pathways, both in total and by parental education, based on the weighted percentages. We distinguished four parental education groups according to the parents' highest educational qualification: (1) no qualification or lower school diploma with or without non-tertiary vocational qualification (CASMIN 1a, 1b, 1c), (2) intermediate school diploma with or without non-tertiary vocational qualification (CASMIN 2a, 2b), (3) tertiary education entrance diploma with or without vocational qualification (CASMIN 2c_voc, 2c_gen), and (4) degrees from universities or universities of applied sciences (CASMIN 3a, 3b). Pathway 1 comprises students who attend the Gymnasium at the lower secondary level (before Grade 10). Most of them enter university (10.2 per cent of all pathways); others enter a university of applied science (2.3 per cent) or do not enrol in tertiary education (2.0 per cent). Persons classified in 
Pathway 2 also attend the Gymnasium at lower secondary level but additionally gain a vocational qualification. Some enter university afterwards (1.6 per cent); others, a university of applied sciences (1.4 per cent). However, the majority do not continue into tertiary education ( 9.0 per cent). Individuals classified in Pathway 3 do not attend the Gymnasium before Grade 10, but a lower or intermediate school. A minority switch to an upper secondary school offering a higher education entrance certificate and continue to university
(1.9 per cent) or a university of applied sciences (1.1 per cent). The majority do not enter tertiary education (11.6 per cent). Pathway 4 comprises students who attend lower or intermediate schools at lower secondary level and obtain a vocational qualification. Some of them attain eligibility before, during, or after completing vocational education and training and enter university ( 1.0 per cent) or a university of applied sciences (2.9 per cent). Most of them do not enter tertiary studies, which is the most common of all pathways (55.1 per cent).

Table 2. Prevalence of educational pathways by education of parents

\begin{tabular}{|c|c|c|c|c|c|c|c|}
\hline Pathway & No. ${ }^{1}$ & $\%^{1}$ & $\begin{array}{r}\text { Total } \\
\%^{2} \\
\end{array}$ & $\begin{array}{r}\text { CASMIN } \\
1 a, 1 b, 1 c \\
\%^{2} \\
\end{array}$ & $\begin{array}{r}\text { CASMIN } \\
2 a, 2 b \\
\%^{2} \\
\end{array}$ & $\begin{array}{r}\text { CASMIN } \\
\text { 2c_voc, } \\
\text { 2c_gen } \\
\%^{2}\end{array}$ & $\begin{array}{r}\text { CASMIN } \\
3 a, 3 b \\
\%^{2}\end{array}$ \\
\hline $1 a$ & 1,191 & 15.5 & 10.2 & 3.5 & 11.1 & 18.3 & 35.5 \\
\hline $1 b$ & 284 & 3.7 & 2.3 & 1.2 & 2.6 & 3.4 & 6.6 \\
\hline $1 c$ & 133 & 1.7 & 2 & 1.4 & 2.4 & 3.1 & 3.3 \\
\hline $2 a$ & 180 & 2.3 & 1.6 & 0.6 & 2 & 2.3 & 4.9 \\
\hline $2 b$ & 155 & 2 & 1.4 & 0.7 & 1.7 & 2.1 & 3.6 \\
\hline $2 c$ & 783 & 10.2 & 9 & 7 & 12.5 & 12.4 & 11.6 \\
\hline $3 a$ & 190 & 2.5 & 1.9 & 1.2 & 2.8 & 3 & 3.4 \\
\hline $3 b$ & 115 & 1.5 & 1.1 & 0.9 & 1.3 & 1.2 & 1.6 \\
\hline $3 c$ & 554 & 7.2 & 11.6 & 14.4 & 9.1 & 9.9 & 3.1 \\
\hline $4 a$ & 126 & 1.6 & 1 & 0.9 & 1.1 & 1.8 & 1.1 \\
\hline $4 b$ & 301 & 3.9 & 2.9 & 2.6 & 3 & 4.5 & 2.9 \\
\hline $4 c$ & 3,657 & 47.7 & 55.1 & 65.6 & 50.3 & 38 & 22.3 \\
\hline Total (No.) & 7,669 & 7,669 & 7,669 & 4,664 & 1,451 & 549 & 1,005 \\
\hline Total (\%) & 100.0 & 100.0 & 100.0 & 100.0 & 100.0 & 100.0 & 100.0 \\
\hline
\end{tabular}

Notes. Source: NEPS: SC6: 1.0.0; own calculations.

${ }^{1}$ Unweighted.

${ }^{2}$ Standardized weights based on Mikrozensus 2009.

The distribution over pathways depends strongly on the parents' education: the higher the latter, the more likely are pathways in which students attend the Gymnasium at lower secondary level (1a-2c). The strongest differences by parental education prevail in Pathway 1a. Whereas 35.5 per cent of students whose parents have tertiary degrees attend the Gymnasium before Grade 10 and enrol in tertiary studies later without completing any vocational training before (Pathway 1a), only 3.5 per cent of those whose parents have no more than basic vocational training above and beyond compulsory schooling do so. By contrast, the share of students entering tertiary education without having attended the Gymnasium at lower secondary level (Pathways 3a, 3b, 4a, 4b) is distributed more equally with regard to parental education. The percentage of students not attending the Gymnasium and not entering tertiary education (Pathways 3c and 4c), however, is much higher if parents are less educated. 


\section{Theoretical considerations and hypotheses}

This section considers explanations for why and when students drop out. First, we discuss mechanisms linking pre-tertiary pathways and dropout from higher education. Then, we explain how social origin might relate to both (pre-tertiary pathways and dropout). Finally, we reflect on the role of time.

\section{Mechanisms linking pre-tertiary pathways and dropout from higher education}

Previous research has shown that students at the same level of initial competencies develop differently according to which track they are assigned to (Hanushek \& Wössmann, 2006; Maaz, Trautwein, Lüdtke, \& Baumert, 2008; Trautwein, Lüdtke, Marsh, Köller, \& Baumert, 2006). Due to institutional (e.g. curricula, timetables, education of teachers) and compositional differences (distribution of achievement and social background), progress in competencies is higher at the Gymnasium (Maaz et al., 2008). Although the majority of tertiary students, including those who have previously attended a lower or intermediate track, attained eligibility in senior classes of the highest track (Gymnasiale Oberstufe), there might be negative long-term effects. First, it is unlikely that three years of senior classes overwrite the effects of about five years of tracking at lower secondary level. Second, tertiary students who have attended lower or intermediate tracks at lower secondary level are more likely to join senior classes that are more heterogeneous in terms of achievement and social background (see Maaz, Chang, \& Köller, 2004). Beyond effects on competencies, tracking also gives the opportunity to meet students with certain characteristics, and this may shape aspirations (Hallinan \& Williams, 1990). Students on upwardly mobile paths are more likely to become acquainted with persons not entering tertiary education. Values shared in these friendships might be opposed to higher educational aspirations and might render integration into tertiary education more difficult (Tinto, 1975). The example given by friends might make educational or occupational alternatives appear more desirable than continuing tertiary education.

Tracking was found to have an effect on students' self-concepts. On the one hand, students in schools with lower average achievement develop higher academic self-concepts (big-fish-little-pond effect (BFLP), Marsh \& Parker, 1984; for evidence on the German education system, see e.g. Trautwein et al., 2006). On the other hand, students in selective schools might develop higher academic self-concepts because they attribute the positive collective identity to themselves (basking-in-thereflected-glory effect (BIRG), Cialdini et al., 1976; for evidence on the German education system, see e.g. Knigge \& Hannover, 2011). However, the latter seems to be much weaker than the BFLP effect (Marsh, Kong, \& Hau, 2000; Trautwein et al., 2006). Having formed a high level of academic self-concept at school, students who enter tertiary education via upwardly mobile pathways might experience substantial losses of academic self-concept when they arrive at an institution in which the average performance level is higher.

Drawing on differential learning environments and their effects on competencies, social relations, and self-concepts, we therefore expect that students who reach higher education from outside the standard academic track of the Gymnasium, will have higher dropout risks (Hypothesis 1).

In Germany, vocational education and tertiary education are particularly strongly divided within the general education system and have developed along separate paths for the last 200 years (Baethge, 2010, p. 281). Vocational and general education, therefore, differ in institutional characteristics. For example, the main goal in vocational education is to impart competencies related to an occupational field, whereas in general education, it is to develop the personality and to promote autonomy. Moreover, whereas vocational education is organized as a combination of practical work on the job and learning that is related to practical tasks at school, general education is mainly theoretical (Baethge, 2010, pp. 278-280).

This strong division between non-tertiary vocational education plus training (VET) and tertiary education in the German education system, renders the transition from VET to tertiary education particularly difficult (Powell \& Solga, 2011, p. 54). Students with vocational qualifications who enrol in tertiary education might be frustrated due to the lack of recognition of prior qualifications, and they might find it difficult to adapt to the stronger theoretical orientation.

Following a reformulation of the rational-choice model on educational decisions, the key 
determinants of the decision between tertiary and vocational education and the labour market can be considered to be the subjective probability of success, the expected income, and the time horizon (i.e. the time span taken into account for calculating the returns; see Hillmert \& Jacob, 2003). If these determinants explain the decision to enter tertiary education after obtaining a vocational qualification, any changes occurring in them might lead to a revision of this decision and to a dropout from tertiary studies. Empirical evidence shows that students adjust their perceptions of the probability that they will succeed in tertiary education after receiving feedback through, for example, grades (Stinebrickner \& Stinebrickner, 2012). Because students with vocational qualifications who drop out can anticipate the income of a skilled rather than an unskilled employee, their expected income gains through tertiary education will be lower. As a result, they might be more sensitive to reductions in their perceived probability of success. Due to the difficult transition from non-tertiary vocational education to tertiary education and the lower additional benefits of graduation, we therefore expect higher dropout risks for vocationally qualified students than for students without prior vocational qualification (Hypothesis 2 ).

Being the most direct pathway to tertiary education, the standard academic pathway via the Gymnasium is usually also the shortest in duration. Students who additionally obtain a vocational qualification before or after acquiring eligibility for tertiary studies, are therefore older when they enter tertiary studies. Older students might be under stronger time constraints because they are more likely to have children or to work longer hours in a job (DesJardins, Ahlburg, \& McCall, 1999, p. 385; Smith \& Naylor, 2000). We therefore expect older students to be more prone to drop out, and that age at enrolment will explain part of the higher dropout rates of pathways other than the Gymnasium, especially those including vocational qualifications (Hypothesis 3).

Universities have always been the central institutions of the German tertiary education system. Universities of applied sciences emerged from the non-tertiary vocational system and only later became recognised as tertiary institutions. In line with their origins, they are more practically oriented than academic universities (Mayer et al., 2007 , p. 244). Thus, the transfer from more vocationally oriented schools or vocational training to a university of applied sciences, might be smoother than that to a university. Moreover, the prior pathways leading to universities of applied sciences are more heterogeneous (see Scheller, Isleib, \& Sommer, 2013 and the descriptive section in this paper, esp. Table 3). Thus, students who arrive at a university of applied sciences via nonstandard pathways meet peers who share their school experience. This might ease integration. Consequently, we expect the effects of pre-tertiary pathways to be less pronounced at a university of applied sciences than at an academic university (Hypothesis 4).

\section{The role of social origins}

As mentioned above, educational pathways before higher education are class-specific (Table 2; see also Becker \& Hecken, 2009; Jacob \& Weiss, 2010; Reimer \& Pollak, 2010): students from higher social classes have taken the standard path more often than students from lower classes. If pathways outside the academic track produce higher dropout rates, this should result in a social inequality of dropout (Hypothesis 5).

According to Tinto (1975), successful integration into the tertiary social and academic environment helps prevent students from dropout. Thus, students who engage more strongly in extracurricular activities and manage to establish a social network or those who find it easier to comply with the academic requirements based on the values and norms of the university system, are considered to be at less risk of quitting tertiary studies before graduation. Similar arguments can be found in studies following the tradition of Bourdieu (Reay, Davies, David \& Ball, 2001; Thomas \& Quinn, 2006) that highlight the rifts between the habitus of origin and the institutional habitus, and show how difficult they are to overcome for students from a lower social background. Hansen and Mastekaasa (2006), for example, found that after controlling for the secondary school gradepoint average, students at Norwegian universities gain higher grades when they have higher levels of cultural capital.

According to the principle of relative risk aversion (Breen \& Goldthorpe, 1997), students assign priority to the goal of avoiding downward social class mobility when taking educational decisions. Students whose parents have a higher education degree, risk a status loss by dropping out 
of higher education. Hence, dropout involves higher costs for them compared to students whose parents have no tertiary degrees. Because students with more highly educated parents have access to a higher level of resources, find it easier to integrate into the college environment, and have higher costs of status demotion in case of dropping out, we expect them to have lower dropout rates than students with less well educated parents (Hypothesis 6a).

On the other hand, due to the highly socially selective German education system, a much smaller proportion of students from lower social origins than from higher social origins reach higher education. As a result, tertiary students from lower social origins might be a positive selection in terms of the qualities that help them to succeed in the educational system (Mare, 1980). These qualities might compensate for disadvantages and cancel out the effect of social origin (Hypothesis 6b).

\section{The role of time}

The literature on dropout emphasizes that it should be seen as a process in time (e.g. Chen, 2012; DesJardins, 2003; Tinto, 1988). The transition into tertiary studies can be considered as a succession of different stages (Tinto, 1988) that each have their own specific vulnerability to dropout. In addition, the determinants influencing dropout change over time and vary in the strength of their effects (DesJardins et al., 1999).

Differences in the starting conditions based on different educational histories should converge with the duration of a common history of studies under equal conditions. Students from upwardly mobile pathways who may well be less prepared for higher education might still catch up. Furthermore, newly acquired knowledge should become more important than that acquired before higher education. Consequently, the advantage of students who have taken the standard direct path should decrease over time. Finally, the lack of familiarity with the higher education culture might be overcome by making contact and exchanging ideas and information with other students. Indeed, Pascarella, Pierson, Wolniak, and Terenzini (2004) found that students with lower levels of social and cultural capital improve more strongly in educational outcomes through social interactions and academic activities, than students with higher levels of social and cultural capital. Thus, interactions with other students and academic effort seem to have compensatory potential. Regarding the timing of dropout among students who have already gained vocational qualifications, the driving force might well be cost-benefit calculations. According to human capital theory (e.g. Becker, 1964), the decision to invest in education depends not only on expected returns but also on opportunity costs. The latter are higher for students with vocational qualifications, because their qualification raises the costs of foregone earnings. This should result in an early dropout of students with prior vocational qualifications.

In summary, we expect educational pathways before higher education to lose their impact on dropout rates over the duration of higher education, because socialization and newly gained knowledge in the tertiary environment become more important than knowledge learned at school (Hypothesis 7). We also expect that the effect of a vocational qualification will diminish over study duration because the value of the prior qualification declines over time (Hypothesis 8).

\section{Data and methods}

We tested our hypotheses on data from the National Educational Panel Study (NEPS): Starting Cohort 6 - Adults (Adult Education and Lifelong Learning), doi:10.5157/NEPS:SC6:1.0.0. The NEPS data collection is part of the Framework Programme for the Promotion of Empirical Educational Research, funded by the German Federal Ministry of Education and Research and supported by the Federal States. The study population consists of 11,649 individuals born between 1944 and 1986 who were surveyed for either the first or second time in 2009/2010. Because the entire education and labour market history is surveyed on the basis of spells, i.e. the time spent in a specific state, we can identify starting points, durations, and successful completions of tertiary studies.

We doubt that our arguments apply to study episodes in East Germany before reunification, because access to higher education, study programmes, and the labour market situation differed strongly from conditions in West Germany (see Solga, 1997). Therefore, we dropped school and study episodes in the NEPS sample that were found to have taken place in the German Democratic Republic (GDR). This information is not available for those interviewed for the second time 
in $2009 / 2010$. Thus, respondents of this subsample were disregarded if they were born in East Germany and started secondary or tertiary education before the restructuring of the educational system in 1990.

Because our study is restricted to the German education system, we did not consider individuals who had migrated to Germany after the age of 7 years, had spent more than a year abroad during their school career, or had studied in a tertiary institution abroad.

As only 43 respondents (1.6 per cent of the analysed sample) had missing values on at least one variable of interest, we decided to exclude them listwise from the analysis. Additionally, we excluded 19 cases with extreme values (greater than 40 ) in the variable age at enrolment. For reasons of comparability over time, we did not take into account student entry cohorts before 1970. Although the institutional setting of higher education did not change dramatically afterwards, the recognition of universities of applied sciences as higher education institutions was a major change in the late 1960s.

We restricted our analyses to study episodes at universities and universities of applied sciences (both ISCED-level 5A). We excluded ISCED-level 5B institutions such as universities of cooperative education (Berufsakademien), business academies (Wirtschaftsakademien), or academies of public administration (Verwaltungsakademien) that are not yet recognized comprehensively as university-level institutions by federal law.

We analysed dropout from first tertiary studies as the dependent variable, defined as leaving first tertiary studies without a degree and not attending higher education again within the following 12 months. This definition ensures that we avoid considering changes in the field of studies as dropouts.

For the purpose of the present analysis, we distinguished four types of educational pathway after primary school and before tertiary entrance (see Pathways $1 \mathrm{a}, 1 \mathrm{~b}, 2 \mathrm{a}, 2 \mathrm{~b}, 3 \mathrm{a}, 3 \mathrm{~b}, 4 \mathrm{a}$, and $4 \mathrm{~b}$ in Table 1 , and the respective description in the text). We were not interested in Pathways $1 c, 2 c, 3 c$, and $4 c$, because students in these pathways do not enter tertiary education. Social origin was measured by the parents' highest educational qualification. As mentioned above, we distinguished four parental education groups: (1) no qualification or lower school diploma with or without non-tertiary vocational qualification (CASMIN 1a, 1b, 1c), (2) intermediate school diploma with or without non-tertiary vocational qualification (CASMIN 2a, 2b), (3) tertiary education entrance diploma with or without vocational qualification (CASMIN 2c_voc, 2c_gen), and (4) degrees from universities or universities of applied sciences (CASMIN 3a, 3b). Here again, we did not consider degrees from universities of cooperative education (Berufsakademien), business academies (Wirtschaftsakademien), or academies of public administration (Verwaltungsakademien) as higher education degrees.

We also took into account the respondent's age at entry into higher education derived from the respondent's birth year and the spell data on education.

Finally, all multivariate models include control variables. These are gender, first-year student cohorts, the type of higher education entrance certificate, changing between the two higher education institutions as a time-dependent variable, and the grade-point average of the highest school certificate. The latter variable was used in an attempt to control for primary effects, the relationship between socioeconomic background and performance, as well as the relationship between school performance and educational pathway. In order to achieve better comparability over time, we standardized the gradepoint average by the year of graduation. Additionally, we reversed the standardized values so that higher values indicate better grades. Although the type of higher education entrance certificate is related to the pathway, there is some variation within the pathways with regard to the type of the certificate. We also did not consider collinearity to be a problem. However, we were concerned that grading might differ between school types or, more precisely, that at the same level of competencies, students at other schools than the Gymnasium might obtain better grade-point averages. In this case, the predictive power of the grade-point average on dropout should be stronger for students who obtain their higher education entrance certificate at the Gymnasium than for students who obtain it at a vocational or other school. However, interaction effects between the school type awarding the entrance diploma and the grade-point average were not significant. This convinced us that the quality of the grade-point average as a proxy for primary effects does not differ strongly between school types. For a distribution of all covariates in both samples at different points in time, see Tables $A 1$ and $A 2$ in the Appendix. 
We tested our hypotheses with event history analysis in order to take the time dependency of dropout into account. In a first step, we estimated the following functions indicating the proportion of students who have dropped out $\left(H^{a}\right)$ or completed $\left(H^{b}\right)$ tertiary education until a certain point in time (see Rohwer, 2006):

(1) $H^{a}(t):=\sum_{k=0}^{t-1} r^{a}(k) G(k)$

(2) $H^{b}(t):=\sum_{k=0}^{t-1} r^{b}(k) G(k)$

in which $r^{a}(k)$ represents the transition rate of dropout, $r^{b}(k)$ the transition rate of completion, and $G(k)$ the global survivor function of dropout and completion - that is, the probability of still persisting in tertiary studies at a certain point in time. We computed the survivor function with the KaplanMeier method.

For the multivariate analyses, we estimated transition rate models. The underlying dependent process is the monthly duration in first tertiary studies ending with an event for dropouts. The transition rate is the intensity of experiencing an event under the condition of not having experienced the event before (Blossfeld, Golsch \& Rohwer, 2007). This is given in the following Equation 3:

(3) $r(t)=\lim _{t^{\prime}-t} \frac{P\left(t \leq T<t^{\prime} \mid T \geq t\right)}{t^{\prime}-t}$

in which $T$ is defined as a continuous random variable indicating the duration in tertiary education. Possible destination states are dropout, receiving a degree, or still being in tertiary education at the time of the interview. Whereas the last case is inherently rightcensored, we also treated graduating as rightcensored. We modelled the duration dependence with a piecewise constant exponential model that assumes the baseline hazard rate to be constant within time periods but allows it to vary between them (Blossfeld et al., 2007). A hazard rate for each predefined interval $(l)$ was computed with the following equation, based on the coefficient for the baseline hazard of the interval $\left(\beta_{0 l}\right)$ and the regression coefficients of the covariates $\left(\beta_{1} \ldots \beta_{k}\right)$. Thus, it is assumed that covariates shift the rate proportionally up or down.

(4) $r\left(t_{l}\right)=\exp \left\{\beta_{0 l}+\beta_{1} x_{1}+\ldots+\beta_{k} x_{k}\right\}$

In order to test whether the effects of covariates vary over time, we also estimated period-specific effects that can vary between the time intervals $\left(\beta_{1 l} \ldots \beta_{k l}\right)$ :

(5) $r\left(t_{l}\right)=\exp \left\{\beta_{0 l}+\beta_{1 l} x_{1}+\ldots+\beta_{k l} x_{k}\right\}$
At the time when large proportions of students have already graduated, the remaining population at risk might be highly selective, and this selectiveness might not be independent of studying successfully. We introduced right censoring into the multivariate analysis for cases that have no event during the first 8 years after starting tertiary studies. At this point in time, the risk set comprises 10 per cent of the original risk set at university and 2 per cent of the original risk set at universities of applied sciences. We ran the models separately for academic universities and universities of applied sciences because these two types of higher education institutions differ in important aspects: the composition of students regarding social origins, the composition of students regarding previously taken pathways, the length of study programmes, and the proportion of vocational versus academic orientation.

\section{Results}

In this section, we first present some descriptive results on the prevalence of pre-tertiary educational pathways and on the distribution of dropout and graduation over time, before moving on to the multivariate analyses of dropout.

\section{Descriptive results}

Table 3 shows the distribution of students at university and university of applied sciences over the four types of educational pathway. The weighted percentages give an impression of the prevalence of each pathway in the population. The distribution differs largely between the two types of higher education institution. The majority of first-year students (about 70 per cent) reach university via the standard pathway. At universities of applied sciences, however, the picture is different: here, less than every third student has taken the standard pathway. In comparison to academic university students, more students at the universities of applied sciences have obtained a vocational qualification before entering higher education. The largest group of these students reaches a university of applied sciences via an upwardly mobile pathway combined with non-tertiary vocational training (about 38 per cent). Also, the combination of the standard path-way with a vocational qualification is more frequent at universities of applied sciences (18 per cent) than at academic universities (about 11 per cent). 
Table 3. Prevalence of pre-tertiary educational pathways among students at universities and universities of applied sciences

Universities
Universities of applied sciences

\begin{tabular}{lrrrrrr} 
Types of pre-tertiary pathways & Freq. $^{\mathbf{1}}$ & $\mathbf{\%}^{\mathbf{1}}$ & $\mathbf{\%}^{\mathbf{2}}$ & Freq. $^{\mathbf{1}}$ & $\mathbf{\%}^{\mathbf{1}}$ & $\mathbf{\%}^{\mathbf{2}}$ \\
\hline (1) Standard pathway & 1,203 & 70.6 & 69.2 & 287 & 33.3 & 30.3 \\
(2) Standard pathway + voc. qual. & 183 & 10.7 & 10.8 & 156 & 18.1 & 18.0 \\
(3) Upwardly mobile pathway & 190 & 11.2 & 12.9 & 116 & 13.4 & 14.0 \\
(4) Upw. mobile pathway + voc. qual. & 128 & 7.5 & 7.1 & 304 & 35.2 & 37.7 \\
\hline Total & 1,704 & 100 & 100 & 863 & 100 & 100
\end{tabular}

Notes. Source: NEPS: SC6: 1.0.0; own calculations.

${ }^{1}$ Unweighted.

${ }^{2}$ Standardized weights based on Mikrozensus 2009.

The functions in Figure 1 and 2 indicate the proportions of students who leave their university or university of applied sciences within 10 years after starting tertiary studies, because they either drop out (solid line) or graduate (dashed line).
Because study programmes take longer at academic universities, students there graduate later than those at universities of applied sciences. In the first 3 years, graduations are extremely rare, but more than half of the dropouts have already taken place.

Figure 1. Proportion functions of dropout and graduation from higher education at universities, based on survivor functions (Kaplan-Meier method)

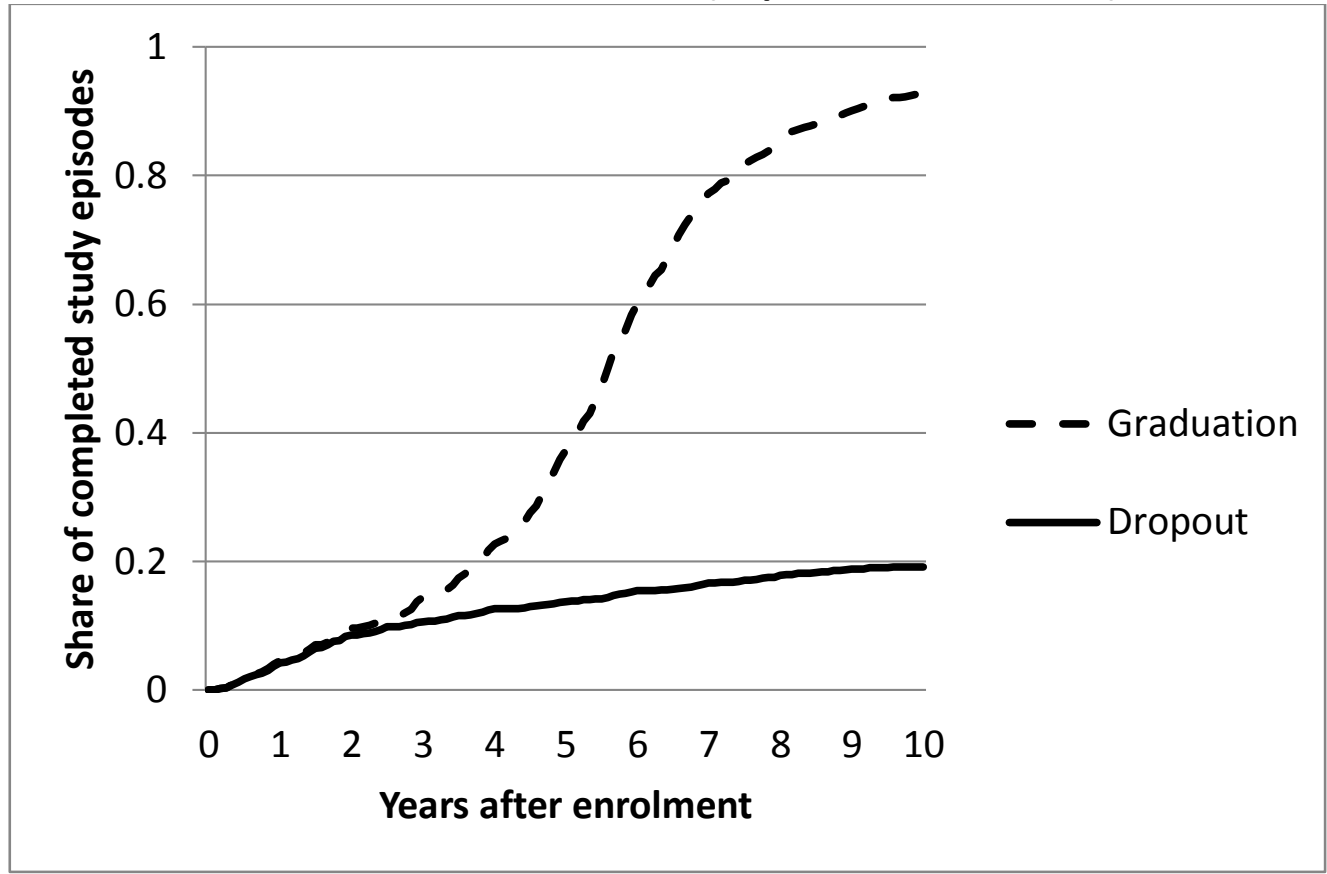

Notes. Source: NEPS SC6; own calculations.

Number of events: 320 dropouts; 1,204 graduations. 
Figure 2. Proportion functions of dropout and graduation from higher education at universities of applied sciences, based on survivor functions (Kaplan-Meier method)

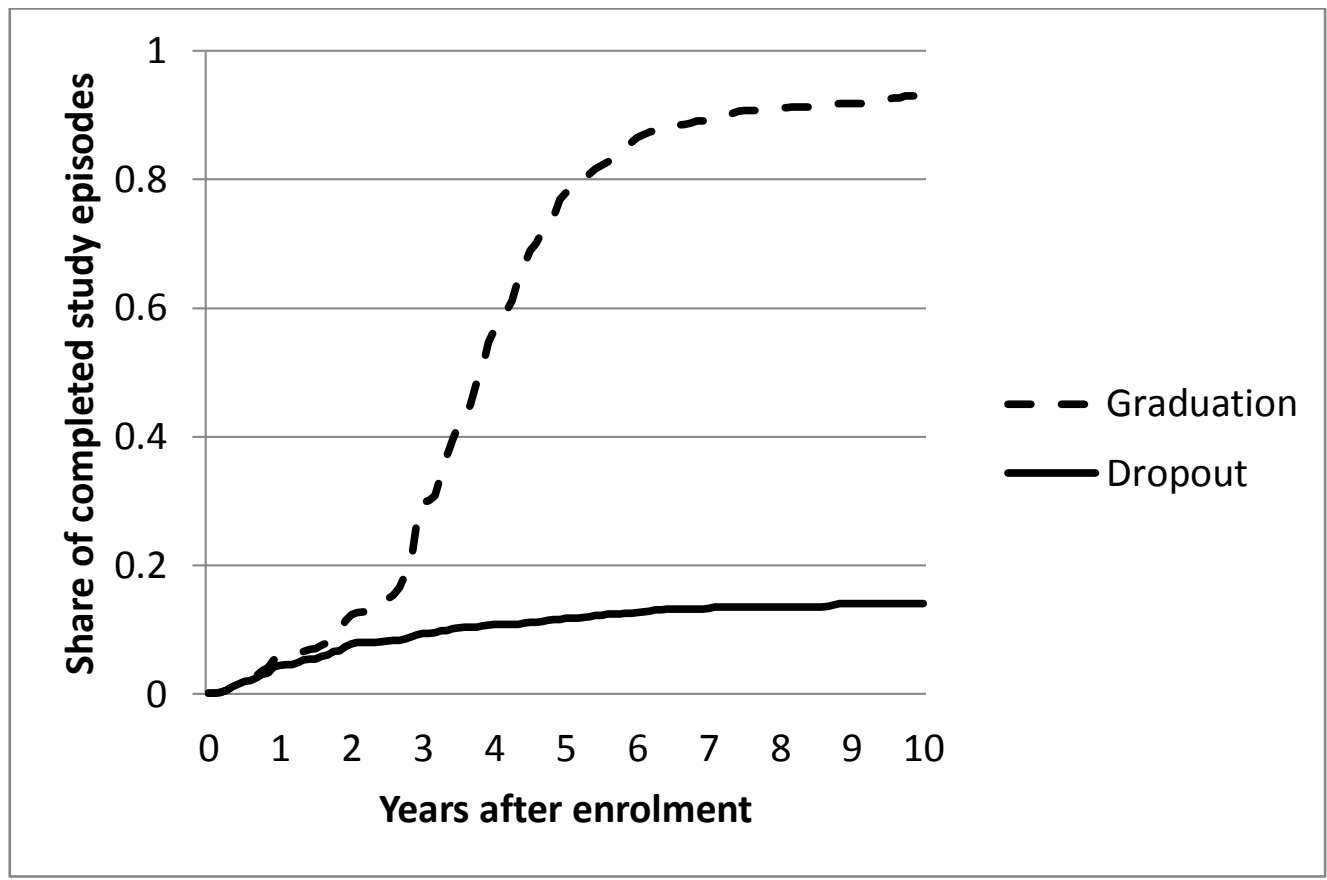

Notes. Source: NEPS SC6; own calculations.

Number of events: 116 dropouts; 705 graduations.

\section{Multivariate results}

We shall start with the findings from the multivariate analysis of university students. We estimated a piece-wise-constant exponential model. The hazard of dropping out does not change over time (see Table 4, Model 1). The risk seems to be time-constant. Regarding social origin, results suggest that students with at least one parent holding a tertiary degree drop out less often from university (see Table 4, Model 1). However, to some extent, this seems to be due to higher academic performance: if the grade-point average of the highest school certificate is controlled (as in Model 2 ), the effect of social origin decreases, although it is still statistically significant on a 10 per cent level.
If, additionally, pre-tertiary pathways are taken into account (see Model 3), the effect of parents with tertiary education declines even more and ceases to be significant ${ }^{2}$. This is in line with the hypothesis that educational pathways explain social inequality in dropout rates to a notable degree (Hypothesis 5). As the remaining effects of parental education are not significant, Hypothesis $6 a$ has to be rejected, whereas findings favour the conflicting Hypothesis 6b: students from a higher social background do not seem to be prevented from dropping out because they can rely on the resources of their parents, they integrate more easily at university, or they have higher dropout costs in terms of status demotion. 
Table 4. Piecewise constant exponential models on dropout from universities within 8 years of starting tertiary studies

\begin{tabular}{|c|c|c|c|c|c|c|}
\hline & Model 1 & Model 2 & Model 3 & Model 4 & Model 5 & Model 6 \\
\hline \multirow[t]{2}{*}{ Year 1} & $-10.53^{*}$ & $-13.56 * *$ & $-11.46^{*}$ & $-11.64 *$ & $-11.55^{*}$ & $-11.72 *$ \\
\hline & [4.89] & [4.88] & {$[4.89]$} & {$[4.87]$} & {$[4.89]$} & {$[4.87]$} \\
\hline \multirow[t]{2}{*}{ Year 2} & $-10.23 *$ & $-13.25^{* *}$ & $-11.15^{*}$ & $-11.33^{*}$ & $-11.18^{*}$ & $-11.36^{*}$ \\
\hline & {$[4.89]$} & [4.88] & [4.89] & {$[4.87]$} & [4.89] & {$[4.87]$} \\
\hline \multirow[t]{2}{*}{ Year 3-4 } & $-10.99 *$ & $-13.99 * *$ & $-11.88^{*}$ & $-12.06 *$ & $-11.94 *$ & $-12.10^{*}$ \\
\hline & [4.89] & {$[4.89]$} & {$[4.90]$} & {$[4.88]$} & {$[4.89]$} & {$[4.88]$} \\
\hline \multirow[t]{2}{*}{ Year 5-8 } & $-10.76 *$ & $-13.77^{* *}$ & $-11.65^{*}$ & $-11.82 *$ & $-11.67 *$ & $-11.83^{*}$ \\
\hline & {$[4.90]$} & [4.90] & {$[4.91]$} & {$[4.89]$} & {$[4.91]$} & {$[4.89]$} \\
\hline Parents: CASMIN 1a/1b/1c & ref. & ref. & ref. & ref. & ref. & ref. \\
\hline \multirow[t]{2}{*}{ Parents: CASMIN 2a/2b } & -0.22 & -0.16 & -0.09 & -0.07 & -0.09 & -0.07 \\
\hline & {$[0.17]$} & {$[0.17]$} & {$[0.17]$} & {$[0.17]$} & {$[0.17]$} & {$[0.17]$} \\
\hline \multirow[t]{2}{*}{ Parents: CASMIN 2c } & 0.07 & 0.16 & 0.24 & 0.23 & 0.24 & 0.23 \\
\hline & [0.19] & [0.19] & [0.19] & [0.19] & {$[0.19]$} & [0.19] \\
\hline \multirow[t]{2}{*}{ Parents: CASMIN 3a/3b } & $-0.42^{* *}$ & $-0.26^{+}$ & -0.14 & -0.12 & -0.13 & -0.12 \\
\hline & {$[0.15]$} & {$[0.15]$} & {$[0.16]$} & {$[0.15]$} & {$[0.16]$} & [0.15] \\
\hline \multirow[t]{2}{*}{ GPA of highest school certificate } & & $-0.67 * *$ & $-0.66 * *$ & $-0.64 * *$ & & \\
\hline & & {$[0.08]$} & {$[0.08]$} & {$[0.08]$} & & \\
\hline \multirow[t]{2}{*}{ in year 1} & & & & & $-0.70^{* *}$ & $-0.68 * *$ \\
\hline & & & & & {$[0.18]$} & {$[0.18]$} \\
\hline \multirow[t]{2}{*}{ in year 2} & & & & & $-0.49 * *$ & $-0.47^{* *}$ \\
\hline & & & & & {$[0.16]$} & {$[0.16]$} \\
\hline \multirow[t]{2}{*}{ in year 3-4 } & & & & & $-0.81^{* *}$ & $-0.78^{* *}$ \\
\hline & & & & & {$[0.17]$} & {$[0.17]$} \\
\hline \multirow[t]{2}{*}{ in year $5-8$} & & & & & $-0.70^{* *}$ & $-0.66^{* *}$ \\
\hline & & & & & {$[0.16]$} & {$[0.15]$} \\
\hline \multirow[t]{2}{*}{ Age at enrolment } & & & & $0.09 * *$ & & $0.09 * *$ \\
\hline & & & & {$[0.02]$} & & {$[0.02]$} \\
\hline Pathway 1 & & & ref. & ref. & ref. & ref. \\
\hline \multirow[t]{2}{*}{ Pathway 2} & & & $0.50 * *$ & 0.15 & & \\
\hline & & & {$[0.18]$} & {$[0.21]$} & & \\
\hline \multirow[t]{2}{*}{ in year $1-2$} & & & & & $0.67 * *$ & 0.32 \\
\hline & & & & & {$[0.23]$} & {$[0.26]$} \\
\hline \multirow[t]{2}{*}{ in year 3-8 } & & & & & 0.30 & -0.05 \\
\hline & & & & & [0.27] & {$[0.29]$} \\
\hline \multirow[t]{2}{*}{ Pathway 3} & & & $0.45^{*}$ & $0.40^{*}$ & & \\
\hline & & & {$[0.18]$} & {$[0.18]$} & & \\
\hline \multirow[t]{2}{*}{ in year $1-2$} & & & & & $0.64 * *$ & $0.59 *$ \\
\hline & & & & & [0.24] & {$[0.24]$} \\
\hline \multirow[t]{2}{*}{ in year 3-8 } & & & & & 0.23 & 0.19 \\
\hline & & & & & {$[0.27]$} & {$[0.27]$} \\
\hline \multirow[t]{2}{*}{ Pathway 4} & & & $0.64^{* *}$ & 0.18 & & \\
\hline & & & {$[0.21]$} & [0.25] & & \\
\hline \multirow[t]{2}{*}{ in year $1-2$} & & & & & 0.40 & -0.06 \\
\hline & & & & & {$[0.31]$} & {$[0.34]$} \\
\hline \multirow[t]{2}{*}{ in year 3-8 } & & & & & $0.85^{* *}$ & 0.39 \\
\hline & & & & & {$[0.27]$} & {$[0.29]$} \\
\hline
\end{tabular}

Notes. Source: NEPS SC6; own calculations. Standard errors in brackets. ${ }^{+} p<0.10,{ }^{*} p<0.05,{ }^{* *} p<0.01$.

Number of persons: 1,704; number of events (dropouts): 289. Controls (not reported in the table for the sake of clarity, see Table A3 in the Appendix for complete results): gender, entry year of tertiary studies (linear and squared), changing from university to a university of applied sciences, type of higher education entrance certificate. Due to low numbers of events per pathway in each single time period, Models 5 and 6 include constraints for educational pathways indicating that the effect for the first year equals the effect for the second year, and the effect for the third and fourth year equals the effect for the fifth to eighth year. 
Model 3 indicates that pre-tertiary pathways seem to matter: students who came to university via the direct standard pathway have significantly lower dropout rates than students with a more complex educational history. This result favours the hypothesis that the learning environment of the Gymnasium eases integration and endurance at university (Hypothesis 1). Pathways with vocational training seem to induce the highest dropout rates. This is consistent with the hypothesis that these students are distracted from higher education more strongly, because of better alternative labour market opportunities and lower relative benefits from higher education, than students without additional vocational qualifications (Hypothesis 2).

In Model 4, we find that older students are more prone to drop out and that this explains higher dropout rates of students who obtained a vocational qualification before tertiary studies as expected in Hypothesis 3. However, pre-tertiary pathways and age at enrolment correlate highly. For example, 75 per cent of university students on Pathways 1 or 3 are respectively 21 years and 1 month and 21 years and 6 months old or younger, whereas 75 per cent of university students on Pathways 2 or 4 are respectively at least 24 years and 10 months and 27 years and 6 months old.

In Models 5 and 6, we introduced time-varying effects in order to test how the influence of the covariates on dropout develops over the duration of tertiary studies - in Model 5 without, and in Model 6 with, controlling for age at enrolment. We find results at the university to be consistent with the hypothesis that pre-tertiary pathways matter more strongly in the beginning and lose their impact later, which might be due to newly acquired knowledge and networks at university (Hypothesis
7). This seems to be the case for at least the standard pathway combined with vocational training and the upwardly mobile pathway without additional vocational qualifications. Students who have taken these pathways before entering university have higher dropout rates in the first 2 years than students who have followed the standard pathway, whereas these effects are less pronounced and not statistically significant afterwards. This is not the case, however, for students who have combined an upwardly mobile pathway and a vocational qualification. These students are more prone to a late dropout after the first 2 years. The effects on early dropout of students in Pathway 2 and the late dropout of students in Pathway 4 are no longer significant when age at enrolment is taken into account (Model 6).

Results for the universities of applied sciences differ from those from academic universities in four major points (see Table 5). First, social origins do not impact on dropout rates, so Hypothesis 5 has to be rejected. Second, vocational qualifications before tertiary education do not increase dropout rates significantly. This supports the hypothesis that the universities of applied sciences are more successful in retaining students with vocational qualifications because of their more practical orientation (Hypothesis 4). Third, older students do not differ significantly from younger students in their dropout risk. Fourth, effects of pre-tertiary pathways do not vary significantly over time. It has to be taken in account, however, that the sample and the total number of dropouts are smaller at universities of applied sciences, and thus the probability of significant effects is lower ${ }^{3}$. 
Table 5. Piecewise constant exponential models on dropout from universities of applied sciences within 8 years of starting tertiary studies

\begin{tabular}{|c|c|c|c|c|c|c|}
\hline & Model 1 & Model 2 & Model 3 & Model 4 & Model 5 & Model 6 \\
\hline \multirow[t]{2}{*}{ Year 1} & -8.51 & $-12.64^{+}$ & $-14.53^{+}$ & $-14.62^{+}$ & $-13.77^{+}$ & $-13.84^{+}$ \\
\hline & [7.22] & [7.37] & [7.45] & [7.48] & {$[7.48]$} & [7.50] \\
\hline \multirow[t]{2}{*}{ Year 2} & -8.74 & $-12.85^{+}$ & $-14.73^{*}$ & $-14.82^{*}$ & $-13.98^{+}$ & $-14.05^{+}$ \\
\hline & [7.22] & {$[7.37]$} & [7.45] & {$[7.48]$} & {$[7.48]$} & {$[7.50]$} \\
\hline \multirow{2}{*}{ Year 3-4 } & -9.11 & $-13.21^{+}$ & $-15.07^{*}$ & $-15.17^{*}$ & $-14.52^{+}$ & $-14.59^{+}$ \\
\hline & [7.23] & {$[7.38]$} & {$[7.46]$} & {$[7.49]$} & {$[7.49]$} & {$[7.52]$} \\
\hline \multirow[t]{2}{*}{ Year 5-8 } & -8.40 & $-12.56^{+}$ & $-14.45^{+}$ & $-14.54^{+}$ & $-13.78^{+}$ & $-13.84^{+}$ \\
\hline & [7.25] & {$[7.40]$} & {$[7.47]$} & {$[7.50]$} & {$[7.51]$} & [7.53] \\
\hline Parents: CASMIN 1a/1b/1c & ref. & ref. & ref. & ref. & ref. & ref. \\
\hline \multirow{2}{*}{ Parents: CASMIN 2a/2b } & -0.23 & -0.19 & -0.17 & -0.18 & -0.18 & -0.19 \\
\hline & {$[0.27]$} & {$[0.27]$} & {$[0.27]$} & {$[0.27]$} & {$[0.27]$} & {$[0.27]$} \\
\hline \multirow[t]{2}{*}{ Parents: CASMIN 2c } & 0.23 & 0.23 & 0.33 & 0.33 & 0.33 & 0.33 \\
\hline & {$[0.32]$} & {$[0.33]$} & [0.33] & [0.33] & {$[0.33]$} & [0.33] \\
\hline \multirow{2}{*}{ Parents: CASMIN 3a/2b } & 0.08 & 0.01 & 0.07 & 0.07 & 0.07 & 0.07 \\
\hline & {$[0.25]$} & {$[0.24]$} & {$[0.25]$} & {$[0.25]$} & {$[0.25]$} & {$[0.25]$} \\
\hline GPA of highest school certificate & & $\begin{array}{c}-0.89 * * \\
{[0.15]}\end{array}$ & $\begin{array}{c}-0.90 * * \\
{[0.15]}\end{array}$ & $\begin{array}{c}-0.90 * * \\
{[0.15]}\end{array}$ & & \\
\hline in year 1 & & & & & $\begin{array}{c}-1.01^{* *} \\
{[0.27]}\end{array}$ & $\begin{array}{c}-1.01 * * \\
{[0.27]}\end{array}$ \\
\hline in year 2 & & & & & $\begin{array}{c}-1.05^{* *} \\
{[0.31]}\end{array}$ & $\begin{array}{c}-1.05^{* *} \\
{[0.31]}\end{array}$ \\
\hline in year 3-4 & & & & & $-0.90^{* *}$ & $-0.90^{* *}$ \\
\hline \multirow[t]{2}{*}{ in year 5-8 } & & & & & -0.53 & -0.53 \\
\hline & & & & & {$[0.33]$} & [0.34] \\
\hline \multirow[t]{2}{*}{ Age at enrolment } & & & & -0.01 & & -0.00 \\
\hline & & & & {$[0.03]$} & & [0.03] \\
\hline Pathway 1 & & & ref. & ref. & ref. & ref. \\
\hline \multirow[t]{2}{*}{ Pathway 2} & & & 0.14 & 0.15 & & \\
\hline & & & {$[0.30]$} & {$[0.32]$} & & \\
\hline \multirow[t]{2}{*}{ in year $1-2$} & & & & & -0.05 & -0.03 \\
\hline & & & & & {$[0.39]$} & {$[0.40]$} \\
\hline \multirow[t]{2}{*}{ in year 3-8 } & & & & & 0.36 & 0.37 \\
\hline & & & & & {$[0.46]$} & {$[0.47]$} \\
\hline \multirow[t]{2}{*}{ Pathway 3} & & & $0.73 *$ & $0.73 *$ & & \\
\hline & & & [0.29] & [0.29] & & \\
\hline \multirow[t]{2}{*}{ in year $1-2$} & & & & & $0.72 *$ & $0.72 *$ \\
\hline & & & & & {$[0.36]$} & {$[0.36]$} \\
\hline \multirow[t]{2}{*}{ in year 3-8 } & & & & & 0.69 & 0.69 \\
\hline & & & & & {$[0.46]$} & {$[0.46]$} \\
\hline \multirow[t]{2}{*}{ Pathway 4} & & & 0.01 & 0.02 & & \\
\hline & & & [0.29] & {$[0.30]$} & & \\
\hline \multirow[t]{2}{*}{ in year $1-2$} & & & & & -0.23 & -0.22 \\
\hline & & & & & {$[0.36]$} & {$[0.37]$} \\
\hline \multirow[t]{2}{*}{ in year 3-8 } & & & & & 0.30 & 0.31 \\
\hline & & & & & {$[0.40]$} & {$[0.41]$} \\
\hline
\end{tabular}

Notes. Source: NEPS SC6; own calculations. Standard errors in brackets. ${ }^{+} p<0.10,{ }^{*} p<0.05,{ }^{* *} p<0.01$.

Number of persons: 863; number of events (dropouts): 113. Controls (not reported in the table for the sake of clarity, see Table A4 in the appendix for complete results): gender, entry year of tertiary studies (linear and squared), changing from a university to a university of applied sciences, type of higher education entrance certificate. We did not control for changing from a university of applied sciences to an academic university because of too few events in this group. Due to low numbers of events in each single time period, Models 5 and 6 include constraints for educational pathways indicating that the effect for the first year equals the effect for the second year, and the effect for the third and fourth year equals the effect for the fifth to eighth year. 


\section{Summary and conclusion}

In this paper, we have analysed the impact of pre-tertiary educational pathways and social origins on dropout rates in higher education, and the role of time in this interplay. Our findings suggest that pre-tertiary pathways have an effect on dropout from higher education. At university, we find that pathways other than the academic track or including a vocational qualification have higher dropout rates than the standard path. This is in line with Hypothesis 1, that students from outside the standard pathway face adaptation difficulties, and that students with vocational qualifications might be less committed to graduating because they have lower additional benefits from a tertiary degree (Hypothesis 2). At the universities of applied sciences, pathways with vocational training do not show significantly higher dropout rates, which might be due to the more practical orientation of the institutions as predicted by Hypothesis 4. The upwardly mobile pathway without vocational qualification, however, is connected to higher dropout rates at the universities of applied sciences as well. The age of students at enrolment to tertiary education seems to explain to a great extent why students with vocational qualifications are more prone to drop out from tertiary education. If age is an approximate measure for the amount of external responsibilities and obligations due to children or a demanding job, this can be interpreted as support for Hypothesis 3. However, further variables would have to be included, such as the birth of a child or working time, in order to have more direct evidence. Moreover, this interpretation has to be viewed with caution, because age at enrolment correlates highly with pre-tertiary pathways, and might therefore serve as an approximate measure of whether students have obtained a vocational qualification or not. As far as social origins are concerned, there is some evidence that, at university, the class-specific choices of educational pathways influence social selectivity in dropout (Hypothesis 5): at university, students with more highly educated parents have lower dropout rates. If the educational pathways are taken into account, the effect of social origins is reduced and ceases to be statistically significant. Thus, we find no support for Hypothesis 6a, that students with more highly educated parents are less prone to drop out due to their access to higher levels of social, cultural, or economic capital or due to the motive of status maintenance, once prior educational decisions are taken into account. However, these prior educational decisions are socially selective. Thus, there might be indirect effects of the motive of status maintenance via the pre-tertiary career. As expected in Hypothesis $6 b$, tertiary students with lower social origins might be positively selected on the basis of unobserved characteristics, which help them to counterbalance the disadvantages of their social background.

As anticipated in Hypotheses 7 and 8, at the universities, the effect of pre-tertiary educational pathways on dropout rates seems to weaken over the duration of studies - at least with respect to the standard pathway with vocational qualification and the upwardly mobile pathway without vocational qualification. At the universities of applied sciences, we do not find this pattern of decreasing effects of educational pathways. Considering that adaptation difficulties might be a major cause for early dropout, this finding fits the hypothesis that at the universities of applied sciences, students from a lower social background and students who reach higher education from outside the standard pathway, experience lower cultural divisions (Hypothesis 4). However, due to the lack of direct measures of adaptation, further research is needed to carefully test this hypothesis in more detail.

Regarding the arguments based on theories of educational decisions, we find that the risk of dropping out of higher education is influenced by decisions taken years before. Because the decisions for educational pathways are class-specific, they partly explain social inequality in dropout. This result confirms the well-established finding that educational decisions are path-dependent (Breen \& Jonsson, 2000; Pfeffer \& Goldrick-Rab, 2011). At the same time, results point in the direction that the dropout decision - although depending on previous class-specific decisions for educational pathways is not influenced directly by social background when previous educational pathways are controlled. This might be interpreted as support for the life-course hypothesis (Shavit \& Blossfeld, 1993) stating that social background loses its impact on decisions as students become adults and more independent from their parents.

Having no means to measure the financial situation of the respondents during their studies, we do not focus on the impact of financial costs on dropout. However, at least we can say that direct 
tuition fees cannot play an important role in our sample, because they were not introduced in Germany until 2005 and impact on only a small proportion of the sample.

Drawing on the concept of differential learning environments, we argued that students are differently socialized and prepared for higher education depending on the educational pathway they have taken beforehand. We find this a plausible explanation for our result that dropout rates differ depending on the pre-tertiary pathway. However, it is not the only possible explanation, and a more precise test of the theoretical concept would require more detailed and direct measures. Apart from path dependency, results also point out that time dependency plays an important role in dropout. Modelling dropout as a process with timespecific dropout intensities can help to reveal sensitive phases in which certain groups are especially vulnerable.

This study contributes to sociological research on higher education in the following ways: First, it uses nationwide longitudinal data to analyse the inclination towards dropout as a process over time. As far as we are aware, this has not been undertaken so far regarding dropout from higher education in Germany. Second, to the best of our knowledge, the study is the first to apply a multivariate approach to investigate the interplay between previous pathways, social origin, and dropout in Germany. This interplay is an important issue for highly stratified education systems with strong social inequality: Education systems such as Germany with its selective and stratified education system and low tertiary graduation rates have a high interest in encouraging permeability to tertiary education in order to increase graduation rates. According to the results of this study, about 30 per cent of students who enter universities and even about two thirds of students who enter universities of applied sciences in Germany have not taken the standard pathway. Instead, they either did not attend the Gymnasium until higher secondary level and/or they completed a vocational qualification before tertiary education. Increasing the nonstandard pathways to higher education, which are used more often by students from a lower social background, seems to be one possible way to reduce social inequality in access to higher education. However, this study finds that tertiary students who have taken non-standard pathways are more vulnerable to drop out from higher education - at least at academic universities, which are the higher education institutions attended by the majority of tertiary students. Thus, on the one hand, non-standard pathways might lead persons who otherwise would not have entered tertiary education to gain a tertiary degree; on the other hand, they are less efficient than standard pathways in terms of leading students to a degree. Therefore, target-oriented support of students with a non-standard educational biography might be a very effective way to counter the loss of potential university graduates during tertiary studies. In our analysis, we suggested some mechanisms that - if further tested with more detailed measures - might give insights into which kind of support is needed. Some answers on how to counter the difficulties of students with different educational biographies might also be found at the more practically oriented universities of applied sciences, in which the dropout propensity does not differ between different pathways.

We find considerable differences between the institutions regarding the effects of covariates on dropout: Parental education, pre-tertiary vocational qualifications, and age, influence dropout at universities but not at universities of applied sciences. Thus, the latter seem to be more successful in attracting and retaining students from lower social backgrounds, with vocational qualifications, and/or with higher ages. Therefore, an expansion of universities of applied sciences might foster permeability between vocational education and tertiary education, and decrease social inequality in the attainment of tertiary degrees. From a critical perspective, however, this could be interpreted as "effectively maintained inequality" (Lucas, 2001), because quantitative inequalities (differences in the proportion of students who complete tertiary education) would be shifted to qualitative inequalities (differences in the distribution over institutions). Following this reasoning, universities would preserve their selectivity, whereas persons with a vocational background and lower social background would be diverted to universities of applied sciences that provide less prestigious degrees and lower labour market returns. However, this would still reduce inequality compared to the status quo in which the expansion of eligibility to tertiary education is leading to students from a lower social background 
being diverted to vocational education rather than to the universities of applied sciences (Lörz, 2013; Mayer et al., 2007).

The present analysis has its limitations, because students select different educational pathways themselves, and this selection is dependent on further characteristics that might also play an important role for dropout from higher education. However, we hope to control for the most important of these characteristics by including the grade-point average of the highest educational certificate as a proxy variable of achievement. Another drawback is that period-specific effects might be caused by the changing composition: less motivated students might leave first, so that the remaining population becomes composed more strongly of students resisting any temptation to drop out. However, by controlling for the gradepoint average of the school leaving certificate, we hope to rule out at least a part of any composition effects.

\section{Acknowledgements}

This work was supported by the German Federal Ministry of Education and Research within the Framework Programme for the Promotion of Empirical Educational Research (section: Support for Young Scientists and Researchers). We would like to thank the anonymous reviewers for their helpful comments and suggestions.

\section{References}

Allmendinger, J. (1989). Educational systems and labor market outcomes. European Sociological Review, 5, 231-250.

Arum, R., Gamoran, A., \& Shavit, Y. (2007). More inclusion than diversion: Expansion, differentiation, and market structure in higher education. In Y. Shavit (Ed.), Stratification in higher education: $A$ comparative study (pp. 1-35). Stanford, CA: Stanford University Press.

Autorengruppe Bildungsberichterstattung. (2012). Bildung in Deutschland 2012: Ein indikatorengestützter Bericht mit einer Analyse zur kulturellen Bildung im Lebenslauf. Bielefeld: Bertelsmann. Retrieved from http://www.bildungsbericht.de/

Ayalon, H., \& Yogev, A. (2005). Field of study and students' stratification in an expanded system of higher education: The case of Israel. European Sociological Review, 21, 227-241.

Baethge, M. (2010). Neue soziale Segmentationsmuster in der beruflichen Bildung. In H.-H. Krüger, U. RabeKleberg, R.-T. Kramer, \& J. Budde (Eds.), Bildungsungleichheit revisited. Bildung und soziale Ungleichheit vom Kindergarten bis zur Hochschule (1st ed., pp. 275-298). Wiesbaden: VS Verlag für Sozialwissenschaften.

Becker, G. S. (1964). Human capital: A theoretical and empirical analysis, with special reference to education. New York, NY: Columbia University Press.

Becker, R., \& Hecken, A. E. (2009). Why are working-class children diverted from universities? An empirical assessment of the diversion thesis. European Sociological Review, 25, 233-250.

Blossfeld, H.-P., Golsch, K., \& Rohwer, G. (2007). Event history analysis with Stata. Mahwah, N.J: Lawrence Erlbaum Associates.

Breen, R., \& Goldthorpe, J. H. (1997). Explaining educational differentials: Towards a formal rational action theory. Rationality and Society, 9, 275-305.

Breen, R., \& Jonsson, J. O. (2000). Analyzing educational careers: A multinomial transition model. American Sociological Review, 65, 754-772.

Chen, R. (2012). Institutional characteristics and college student dropout risks: A multilevel event history analysis. Research in Higher Education, 53, 487-505.

Cialdini, R. B., Borden, R. J., Thorne, A., Walker, M. R., Freeman, S., \& Sloan, L. R. (1976). Basking in reflected glory: Three (football) field studies. Journal of Personality and Social Psychology, 34, 366-375.

DesJardins, S. L. (2003). Event history methods: Conceptual issues and an application to student departure from college. In J. C. Smart \& W. G. Tierney (Eds.), Higher education: Handbook of theory and research (pp. 421-471). Dordrecht, Netherlands: Kluwer Academic.

DesJardins, S. L., Ahlburg, D. A., \& McCall, B. P. (1999). An event model of student departure. Economics of Education Review, 18, 375-390.

Hallinan, M. T., \& Williams, R. A. (1990). Students' characteristics and the peer-influence process. Sociology of Education, 63, 122-132.

Hansen, M. N., \& Mastekaasa, A. (2006). Social origins and academic performance at university. European Sociological Review, 22, 277-291.

Hanushek, E. A., \& Wössmann, L. (2006). Does educational tracking affect performance and inequality? Differences-in-differences evidence across countries. The Economic Journal, 116, C63-76. 
Heublein, U., Hutzsch, C., \& Schreiber, J. (2010). Ursachen des Studienabbruchs in Bachelor- und in herkömmlichen Studiengängen. Ergebnisse einer bundesweiten Befragung von Exmatrikulierten des Studienjahres 2007/08. HIS:Forum Hochschule F02/2010. Retrieved from http://www.his.de/pdf/pub fh/fh-201002.pdf

Hillmert, S., \& Jacob, M. (2003). Social inequality in higher education. Is vocational training a pathway leading to or away from university? European Sociological Review, 19, 319-334.

Hillmert, S., \& Jacob, M. (2010). Selections and social selectivity on the academic track: A life-course analysis of educational attainment in Germany. Research in Social Stratification and Mobility, 28, 59-76.

Jacob, M., \& Weiss, F. (2010). Soziale Selektivität beim Hochschulzugang. Veränderungen der Zugangssequenzen zur Hochschule im Kohortenvergleich. In B. Becker \& D. Reimer (Eds.), Vom Kindergarten bis zur Hochschule. Die Generierung von ethnischen und sozialen Disparitäten in der Bildungsbiographie (pp. 285-312). Wiesbaden, Germany: VS Verlag für Sozialwissenschaften.

Knigge, M., \& Hannover, B. (2011). Collective school-type identity: Predicting students' motivation beyond academic self-concept. International Journal of Psychology, 46, 191-205.

Lörz, M. (2013). Differenzierung des Bildungssystems und soziale Ungleichheit: Haben sich mit dem Ausbau der beruflichen Bildungswege die Ungleichheitsmechanismen verändert? Zeitschrift für Soziologie, 42, 118-136.

Lörz, M., \& Schindler, S. (2009). Educational expansion and effects on the transition to higher education: Has the effect of social background characteristics declined or just moved to the next stage? In A. Hadjar \& R. Becker (Eds.), Expected and unexpected consequences of the educational expansion in Europe and the US. Theoretical approaches and empirical findings in comparative perspective (pp. 97-110). Bern, Switzerland: Haupt.

Lucas, S. (2001). Effectively Maintained Inequality: Education Transitions, Track Mobility, and Social Background Effects. American Journal of Sociology, 106, 1642-1690.

Maaz, K., Chang, P.-H., \& Köller, O. (2004). Führt institutionelle Vielfalt zur Öffnung im Bildungssystem? Sozialer Hintergrund und kognitive Grundfähigkeit der Schülerschaft an allgemein bildenden und beruflichen Gymnasien. In O. Köller, R. Watermann, U. Trautwein, \& O. Lüdtke (Eds.), Wege zur Hochschulreife in Baden-Württemberg. TOSCA - eine Untersuchung an allgemein bildenden und beruflichen Gymnasien (pp. 153-204). Opladen, Germany: Leske und Budrich.

Maaz, K., Trautwein, U., Lüdtke, O., \& Baumert, J. (2008). Educational transitions and differential learning environments: How explicit between-school tracking contributes to social inequality in educational outcomes. Child Development Perspectives, 2, 99-106.

Mare, R. D. (1980). Social background and school continuation decisions. Journal of the American Statistical Association, 75, 295-305.

Marsh, H. W., Kong, C.-K., \& Hau, K.-T. (2000). Longitudinal multilevel models of the big-fish-little-pond effect on academic self-concept: Counterbalancing contrast and reflected-glory effects in Hong Kong schools. Journal of Personality and Social Psychology, 78, 337-349.

Marsh, H. W., \& Parker, J. W. (1984). Determinants of student self-concept: Is it better to be a relatively large fish in a small pond even if you don't learn to swim as well? Journal of Personality and Social Psychology, 47, 213-231.

Mayer, K. U., Müller, W., \& Pollak, R. (2007). Germany: Institutional change and inequalities of access in higher education. In Y. Shavit (Ed.), Stratification in higher education: A comparative study (pp. 240265). Stanford, CA: Stanford University Press.

Müller, W., Brauns, H., \& Steinmann, S. (2002). Expansion und Erträge tertiärer Bildung in Deutschland, Frankreich und im Vereinigten Königreich. Berliner Journal für Soziologie, 12, 37-62.

Müller, W., \& Pollak, R. (2004). Weshalb gibt es so wenige Arbeiterkinder in Deutschlands Universitäten? In R. Becker \& W. Lauterbach (Eds.), Bildung als Privileg? Erklärungen und Befunde zu den Ursachen der Bildungsungleichheit (pp. 311-352). Wiesbaden, Germany: VS Verlag für Sozialwissenschaften.

OECD (2012). Education at a glance 2012: OECD indicators. Paris, France: OECD Publishing. Retrieved from http://www.oecd.org/edu/EAG\%202012 e-book EN 200912.pdf

Pascarella, E. T., Pierson, C. T., Wolniak, G. C., \& Terenzini, P. T. (2004). First-generation college students: Additional evidence on college experiences and outcomes. Journal of Higher Education, 75, 249-284.

Pfeffer, F. T., \& Goldrick-Rab, S. (2011). Unequal pathways through American universities. Institute for Research on Poverty: Discussion Paper no. 1391-11. Retrieved from http://www.irp.wisc.edu/publications/dps/pdfs/dp139111.pdf

Powell, J. J., \& Solga, H. (2011). Why are higher education participation rates in Germany so low? Institutional barriers to higher education expansion. Journal of Education and Work, 24, 49-68.

Reay, D., Davies, J., David, M., \& Ball, S. J. (2001). Choices of degree or degrees of choice? Class, "race" and the higher education choice process. Sociology, 35, 855-874.

Reimer, D., \& Pollak, R. (2010). Educational expansion and its consequences for vertical and horizontal inequalities in access to higher education in West Germany. European Sociological Review, 26, 415430. 
Rohwer, G. (2006). Verweildauern und Übergangsraten bei mehreren Folgezuständen. In A. Diekmann (Ed.), Methoden der Sozialforschung (pp. 348-367). Wiesbaden, Germany: VS Verlag für Sozialwissenschaften.

Scheller, P., Isleib, S., \& Sommer, D. (2013). Studienanfängerinnen und Studienanfänger im Wintersemester 2011/12: Tabellenband. Forum Hochschule: 6/2013. Hannover: HIS, Hochschul-Informations-System. Retrieved from http://www.his.de/pdf/pub fh/fh-201306.pdf

Shavit, Y., \& Blossfeld, H.-P. (1993). Persisting barriers: Changes in educational opportunities in thirteen countries. In Y. Shavit \& H.-P. Blossfeld (Eds.), Persisting inequality: Changing educational attainment in thirteen countries (pp. 1-23). Boulder, CO: Westview Press.

Smith, J. P., \& Naylor, R. A. (2001). Dropping out of university: A statistical analysis of the probability of withdrawal for UK university students. Journal of the Royal Statistical Society: Series A (Statistics in Society), 164, 389-405.

Solga, H. (1997). Bildungschancen in der DDR. In S. Häder, H.-E. Tenorth, \& O. Anweiler (Eds.), Bildungsgeschichte einer Diktatur. Bildung und Erziehung in SBZ und DDR im historischgesellschaftlichen Kontext (pp. 257-274). Weinheim, Germany: Deutscher Studien Verlag.

Statistisches Bundesamt. (2012). Bildung und Kultur: Nichtmonetäre hochschulstatistische Kennzahlen. 19802011. Fachserie 11. Reihe 4.3.1. Wiesbaden. Retrieved from https://www.destatis.de/DE/Publikationen/Thematisch/BildungForschungKultur/Hochschulen/Kenn zahlenNichtmonetaer2110431117004.pdf? blob=publicationFile

Stinebrickner, T., \& Stinebrickner, R. (2012). Learning about Academic Ability and the College Dropout Decision. Journal of Labor Economics, 30, 707-748.

Thomas, L., \& Quinn, J. (2006). First generation entry into higher education: An international study. Buckingham, England: Open University Press.

Tinto, V. (1975). Dropout from higher education: A theoretical synthesis of recent research. Review of Educational Research, 45, 89-125.

Tinto, V. (1988). Stages of student departure: Reflections on the longitudinal character of student leaving. The Journal of Higher Education, 59, 438-455.

Trautwein, U., Lüdtke, O., Marsh, H. W., Köller, O., \& Baumert, J. (2006). Tracking, grading, and student motivation: Using group composition and status to predict self-concept and interest in ninth-grade mathematics. Journal of Educational Psychology, 98, 788-806. 


\section{Appendix}

Table A1. Distribution of characteristics in the sample at certain points in time at universities

\begin{tabular}{|c|c|c|c|c|c|c|}
\hline & \multicolumn{2}{|l|}{ Year 0} & \multicolumn{2}{|l|}{ Year 2} & \multicolumn{2}{|l|}{ Year 5} \\
\hline & No. & $\%$ & No. & $\%$ & No. & $\%$ \\
\hline Men & 921 & 54 & 834 & 54.4 & 577 & 57.4 \\
\hline Women & 783 & 46 & 700 & 45.6 & 429 & 42.6 \\
\hline \multicolumn{7}{|l|}{ Entry cohort } \\
\hline 1970-1979 & 380 & 22.3 & 356 & 23.2 & 224 & 22.3 \\
\hline 1980-1989 & 566 & 33.2 & 518 & 33.8 & 407 & 40.5 \\
\hline 1990-1999 & 343 & 20.1 & 311 & 20.3 & 212 & 21.1 \\
\hline 2000-2010 & 415 & 24.4 & 349 & 22.8 & 163 & 16.2 \\
\hline \multicolumn{7}{|l|}{ HE entrance certificate } \\
\hline Other & 68 & 4 & 54 & 3.5 & 31 & 3.1 \\
\hline General & 1,636 & 96 & 1,480 & 96.5 & 975 & 96.9 \\
\hline Change of HE institution & 0 & 0 & 25 & 1.6 & 36 & 3.6 \\
\hline \multicolumn{7}{|l|}{ Field of study } \\
\hline Medicine & 168 & 9.9 & 160 & 10.4 & 120 & 11.9 \\
\hline Teacher training & 360 & 21.1 & 334 & 21.8 & 173 & 17.2 \\
\hline Humanities/Arts & 293 & 17.2 & 257 & 16.8 & 171 & 17 \\
\hline \multicolumn{7}{|l|}{ Natural } \\
\hline sciences/Mathematics & 283 & 16.6 & 251 & 16.4 & 187 & 18.6 \\
\hline Engineering & 197 & 11.6 & 176 & 11.5 & 126 & 12.5 \\
\hline Law & 104 & 6.1 & 94 & 6.1 & 60 & 6 \\
\hline Business/Economics & 200 & 11.7 & 172 & 11.2 & 115 & 11.4 \\
\hline Other & 99 & 5.8 & 90 & 5.9 & 54 & 5.4 \\
\hline \multicolumn{7}{|l|}{ Parent's education } \\
\hline CASMIN 1a/1b/1c & 478 & 28.1 & 418 & 27.2 & 290 & 28.8 \\
\hline CASMIN 2a/2b & 366 & 21.5 & 333 & 21.7 & 198 & 19.7 \\
\hline CASMIN 2c & 198 & 11.6 & 175 & 11.4 & 109 & 10.8 \\
\hline CASMIN 3a/3b & 662 & 38.8 & 608 & 39.6 & 409 & 40.7 \\
\hline \multicolumn{7}{|l|}{ Pathway } \\
\hline Pathway 1 & 1,203 & 70.6 & 1,115 & 72.7 & 747 & 74.3 \\
\hline Pathway 2 & 183 & 10.7 & 144 & 9.4 & 83 & 8.3 \\
\hline Pathway 3 & 190 & 11.2 & 165 & 10.8 & 109 & 10.8 \\
\hline Pathway 4 & 128 & 7.5 & 110 & 7.2 & 67 & 6.7 \\
\hline \multicolumn{7}{|l|}{ GPA of highest school } \\
\hline certificate (mean) & 0.087 & & 0.119 & & 0.156 & \\
\hline Age at HE entry & 21.32 & & 21.2 & & 21.08 & \\
\hline Total & 1,704 & 100 & 1,534 & 100 & 1,006 & 100 \\
\hline
\end{tabular}

Source: NEPS: SC6: 1.0.0; own calculations. 
Table A2. Distribution of characteristics in the sample at certain points in time at universities of applied sciences

\begin{tabular}{|c|c|c|c|c|c|c|}
\hline & \multicolumn{2}{|l|}{ Year 0} & \multirow{2}{*}{$\begin{array}{c}\text { Year } 2 \\
\text { No. }\end{array}$} & \multicolumn{3}{|c|}{ Year 5} \\
\hline & No. & $\%$ & & $\%$ & No. & $\%$ \\
\hline Men & 555 & 64.3 & 472 & 62.8 & 101 & 61.6 \\
\hline Women & 308 & 35.7 & 279 & 37.2 & 63 & 38.4 \\
\hline \multicolumn{7}{|l|}{ Entry cohort } \\
\hline 1970-1979 & 206 & 23.9 & 188 & 25 & 27 & 16.5 \\
\hline 1980-1989 & 254 & 29.4 & 233 & 31 & 58 & 35.4 \\
\hline 1990-1999 & 187 & 21.7 & 164 & 21.8 & 43 & 26.2 \\
\hline 2000-2010 & 216 & 25 & 166 & 22.1 & 36 & 22 \\
\hline \multicolumn{7}{|l|}{ HE entrance certificate } \\
\hline Other & 411 & 47.6 & 355 & 47.3 & 76 & 46.3 \\
\hline General & 452 & 52.4 & 396 & 52.7 & 88 & 53.7 \\
\hline Change of HE institution & & & 13 & 1.7 & 9 & 5.5 \\
\hline \multicolumn{7}{|l|}{ Field of study } \\
\hline Engineering & 322 & 37.4 & 285 & 38 & 72 & 44.2 \\
\hline Business science & 135 & 15.7 & 112 & 14.9 & 21 & 12.9 \\
\hline Social work/Pedagogics & 146 & 17 & 132 & 17.6 & 24 & 14.7 \\
\hline Other & 257 & 29.9 & 221 & 29.5 & 46 & 28.2 \\
\hline \multicolumn{7}{|l|}{ Parent's education } \\
\hline CASMIN 1a/1b/1c & 405 & 46.9 & 363 & 48.3 & 72 & 43.9 \\
\hline CASMIN 2a/2b & 184 & 21.3 & 159 & 21.2 & 35 & 21.3 \\
\hline CASMIN 2c & 77 & 8.9 & 63 & 8.4 & 11 & 6.7 \\
\hline CASMIN 3a/3b & 197 & 22.8 & 166 & 22.1 & 46 & 28 \\
\hline \multicolumn{7}{|l|}{ Pathway } \\
\hline Pathway 1 & 287 & 33.3 & 257 & 34.2 & 53 & 32.3 \\
\hline Pathway 2 & 156 & 18.1 & 136 & 18.1 & 28 & 17.1 \\
\hline Pathway 3 & 116 & 13.4 & 96 & 12.8 & 21 & 12.8 \\
\hline Pathway 4 & 304 & 35.2 & 262 & 34.9 & 62 & 37.8 \\
\hline GPA of highest school certificate (mean) & -0.029 & & 0.006 & & -0.066 & \\
\hline Age at HE entry & 22.33 & & 22.20 & & 22.26 & \\
\hline Total & 863 & & 751 & & 164 & \\
\hline
\end{tabular}

Source: NEPS: SC6: 1.0.0; own calculations.

Table A3. Piecewise constant exponential models on dropout from universities within 8 years of starting tertiary studies

\begin{tabular}{lcccccc} 
& Model 1 & Model 2 & Model 3 & Model 4 & Model 5 & Model 6 \\
\hline Year 1 & $-10.53^{*}$ & $-13.56^{* *}$ & $-11.46^{*}$ & $-11.64^{*}$ & $-11.55^{*}$ & $-11.72^{*}$ \\
& {$[4.89]$} & {$[4.88]$} & {$[4.89]$} & {$[4.87]$} & {$[4.89]$} & {$[4.87]$} \\
Year 2 & $-10.23^{*}$ & $-13.25^{* *}$ & $-11.15^{*}$ & $-11.33^{*}$ & $-11.18^{*}$ & $-11.36^{*}$ \\
& {$[4.89]$} & {$[4.88]$} & {$[4.89]$} & {$[4.87]$} & {$[4.89]$} & {$[4.87]$} \\
Year 3-4 & $-10.99^{*}$ & $-13.99^{* *}$ & $-11.88^{*}$ & $-12.06^{*}$ & $-11.94^{*}$ & $-12.10^{*}$ \\
& {$[4.89]$} & {$[4.89]$} & {$[4.90]$} & {$[4.88]$} & {$[4.89]$} & {$[4.88]$}
\end{tabular}




\begin{tabular}{|c|c|c|c|c|c|c|}
\hline (Table A3 cont'd) & Model 1 & Model 2 & Model 3 & Model 4 & Model 5 & Model 6 \\
\hline \multirow[t]{2}{*}{ Year 5-8 } & $-10.76^{*}$ & $-13.77 * *$ & $-11.65^{*}$ & $-11.82^{*}$ & $-11.67^{*}$ & $-11.83^{*}$ \\
\hline & [4.90] & [4.90] & [4.91] & [4.89] & [4.91] & [4.89] \\
\hline \multirow[t]{2}{*}{ Women } & 0.19 & $0.24 *$ & $0.23^{+}$ & $0.28^{*}$ & $0.23^{+}$ & $0.28 *$ \\
\hline & [0.12] & [0.12] & [0.12] & {$[0.12]$} & {$[0.12]$} & {$[0.12]$} \\
\hline \multirow[t]{2}{*}{ Entry year } & 0.12 & 0.17 & 0.12 & 0.08 & 0.12 & 0.08 \\
\hline & [0.11] & [0.11] & {$[0.11]$} & {$[0.11]$} & {$[0.11]$} & {$[0.11]$} \\
\hline \multirow[t]{2}{*}{ Entry year sq. } & -0.00 & -0.00 & -0.00 & -0.00 & -0.00 & -0.00 \\
\hline & {$[0.00]$} & {$[0.00]$} & {$[0.00]$} & {$[0.00]$} & {$[0.00]$} & {$[0.00]$} \\
\hline \multirow[t]{2}{*}{ Change of HE inst. } & -0.15 & -0.26 & -0.21 & -0.19 & -0.24 & -0.21 \\
\hline & {$[0.45]$} & {$[0.45]$} & {$[0.45]$} & {$[0.45]$} & {$[0.45]$} & {$[0.45]$} \\
\hline \multirow[t]{2}{*}{ General HE entrance certificate } & -0.18 & -0.05 & 0.26 & 0.42 & 0.29 & 0.45 \\
\hline & [0.29] & [0.29] & [0.31] & [0.32] & {$[0.31]$} & {$[0.32]$} \\
\hline Parents: CASMIN 1a/1b/1c & ref. & ref. & ref. & ref. & ref. & ref. \\
\hline \multirow[t]{2}{*}{ Parents: CASMIN 2a/2b } & -0.22 & -0.16 & -0.09 & -0.07 & -0.09 & -0.07 \\
\hline & {$[0.17]$} & {$[0.17]$} & {$[0.17]$} & {$[0.17]$} & {$[0.17]$} & {$[0.17]$} \\
\hline \multirow[t]{2}{*}{ Parents: CASMIN 2c } & 0.07 & 0.16 & 0.24 & 0.23 & 0.24 & 0.23 \\
\hline & [0.19] & {$[0.19]$} & [0.19] & {$[0.19]$} & {$[0.19]$} & {$[0.19]$} \\
\hline \multirow[t]{2}{*}{ Parents: CASMIN 3a/3b } & $-0.42 * *$ & $-0.26^{+}$ & -0.14 & -0.12 & -0.13 & -0.12 \\
\hline & [0.15] & {$[0.15]$} & {$[0.16]$} & {$[0.15]$} & {$[0.16]$} & {$[0.15]$} \\
\hline \multirow[t]{2}{*}{ GPA of highest school certificate } & & $-0.67^{* *}$ & $-0.66^{* *}$ & $-0.64 * *$ & & \\
\hline & & {$[0.08]$} & {$[0.08]$} & {$[0.08]$} & & \\
\hline \multirow[t]{2}{*}{ in year 1} & & & & & $-0.70 * *$ & $-0.68 * *$ \\
\hline & & & & & {$[0.18]$} & [0.18] \\
\hline \multirow[t]{2}{*}{ in year 2} & & & & & $-0.49 * *$ & $-0.47 * *$ \\
\hline & & & & & {$[0.16]$} & [0.16] \\
\hline \multirow[t]{2}{*}{ in year 3-4 } & & & & & $-0.81 * *$ & $-0.78 * *$ \\
\hline & & & & & [0.17] & [0.17] \\
\hline \multirow[t]{2}{*}{ in year $5-8$} & & & & & $-0.70 * *$ & $-0.66 * *$ \\
\hline & & & & & {$[0.16]$} & [0.15] \\
\hline \multirow[t]{2}{*}{ Age at enrolment } & & & & $0.09 * *$ & & $0.09 * *$ \\
\hline & & & & [0.02] & & {$[0.02]$} \\
\hline Pathway 1 & & & & ref. & ref. & ref. \\
\hline \multirow[t]{2}{*}{ Pathway 2} & & & $0.50 * *$ & 0.15 & & \\
\hline & & & {$[0.18]$} & {$[0.21]$} & & \\
\hline \multirow[t]{2}{*}{ in year $1-2$} & & & & & $0.67 * *$ & 0.32 \\
\hline & & & & & {$[0.23]$} & {$[0.26]$} \\
\hline \multirow[t]{2}{*}{ in year 3-8 } & & & & & 0.30 & -0.05 \\
\hline & & & & & {$[0.27]$} & {$[0.29]$} \\
\hline \multirow[t]{2}{*}{ Pathway 3} & & & $0.45^{*}$ & $0.40 *$ & & \\
\hline & & & [0.18] & {$[0.18]$} & & \\
\hline \multirow[t]{2}{*}{ in year $1-2$} & & & & & $0.64 * *$ & $0.59 *$ \\
\hline & & & & & {$[0.24]$} & {$[0.24]$} \\
\hline in year 3-8 & & & & & 0.23 & 0.19 \\
\hline & & & & & {$[0.27]$} & {$[0.27]$} \\
\hline Pathway 4 & & & $0.64 * *$ & 0.18 & & \\
\hline & & & {$[0.21]$} & {$[0.25]$} & & \\
\hline in year $1-2$ & & & & & 0.40 & -0.06 \\
\hline & & & & & {$[0.31]$} & {$[0.34]$} \\
\hline in year 3-8 & & & & & $0.85^{* *}$ & 0.39 \\
\hline & & & & & {$[0.27]$} & {$[0.29]$} \\
\hline
\end{tabular}

Notes. Standard errors in brackets. ${ }^{+} p<0.10,{ }^{*} p<0.05,{ }^{*} p<0.01$.Source: NEPS SC6; own calculations. Number of persons: 1,704; number of events (dropouts): 289. Due to low numbers of events per pathway in each single time period, Models 5 and 6 include constraints for educational pathways indicating that the effect for the first year equals the effect for the second year and the effect for the third and fourth year equals the effect for the fifth to eighth year. 
Table A4. Piecewise constant exponential models on dropout from universities of applied sciences within 8 years of starting tertiary studies

\begin{tabular}{|c|c|c|c|c|c|c|}
\hline & Model 1 & Model 2 & Model 3 & Model 4 & Model 5 & Model 6 \\
\hline \multirow[t]{2}{*}{ Year 1} & -8.51 & $-12.64^{+}$ & $-14.53^{+}$ & $-14.62^{+}$ & $-13.77^{+}$ & $-13.84^{+}$ \\
\hline & {$[7.22]$} & [7.37] & {$[7.45]$} & [7.48] & {$[7.48]$} & {$[7.50]$} \\
\hline \multirow[t]{2}{*}{ Year 2} & -8.74 & $-12.85^{+}$ & $-14.73^{*}$ & $-14.82^{*}$ & $-13.98^{+}$ & $-14.05^{+}$ \\
\hline & [7.22] & [7.37] & [7.45] & [7.48] & [7.48] & {$[7.50]$} \\
\hline \multirow[t]{2}{*}{ Year 3-4 } & -9.11 & $-13.21^{+}$ & $-15.07^{*}$ & $-15.17^{*}$ & $-14.52^{+}$ & $-14.59^{+}$ \\
\hline & [7.23] & [7.38] & [7.46] & [7.49] & [7.49] & {$[7.52]$} \\
\hline \multirow[t]{2}{*}{ Year 5-8 } & -8.40 & $-12.56^{+}$ & $-14.45^{+}$ & $-14.54^{+}$ & $-13.78^{+}$ & $-13.84^{+}$ \\
\hline & {$[7.25]$} & [7.40] & {$[7.47]$} & {$[7.50]$} & [7.51] & [7.53] \\
\hline \multirow[t]{2}{*}{ Women } & -0.29 & -0.18 & -0.18 & -0.18 & -0.18 & -0.18 \\
\hline & {$[0.21]$} & {$[0.21]$} & {$[0.21]$} & {$[0.21]$} & {$[0.21]$} & {$[0.21]$} \\
\hline \multirow[t]{2}{*}{ Entry year } & 0.06 & 0.15 & 0.19 & 0.19 & 0.17 & 0.18 \\
\hline & {$[0.16]$} & {$[0.16]$} & [0.17] & [0.17] & {$[0.17]$} & [0.17] \\
\hline \multirow[t]{2}{*}{ Entry year sq. } & -0.00 & -0.00 & -0.00 & -0.00 & -0.00 & -0.00 \\
\hline & {$[0.00]$} & {$[0.00]$} & {$[0.00]$} & {$[0.00]$} & {$[0.00]$} & {$[0.00]$} \\
\hline \multirow[t]{2}{*}{ General HE entrance certificate } & -0.30 & $-0.48^{*}$ & $-0.52 *$ & $-0.52 *$ & $-0.50^{*}$ & $-0.50 *$ \\
\hline & {$[0.20]$} & {$[0.20]$} & {$[0.23]$} & {$[0.23]$} & {$[0.23]$} & {$[0.23]$} \\
\hline Parents: CASMIN 1a/1b/1c & ref. & ref. & ref. & ref. & ref. & ref. \\
\hline \multirow[t]{2}{*}{ Parents: CASMIN 2a/2b } & -0.23 & -0.19 & -0.17 & -0.18 & -0.18 & -0.19 \\
\hline & {$[0.27]$} & {$[0.27]$} & {$[0.27]$} & {$[0.27]$} & {$[0.27]$} & {$[0.27]$} \\
\hline \multirow[t]{2}{*}{ Parents: CASMIN 2c } & 0.23 & 0.23 & 0.33 & 0.33 & 0.33 & 0.33 \\
\hline & {$[0.32]$} & {$[0.33]$} & {$[0.33]$} & {$[0.33]$} & [0.33] & {$[0.33]$} \\
\hline \multirow[t]{2}{*}{ Parents: CASMIN 3a/3b } & 0.08 & 0.01 & 0.07 & 0.07 & 0.07 & 0.07 \\
\hline & {$[0.25]$} & {$[0.24]$} & {$[0.25]$} & {$[0.25]$} & {$[0.25]$} & {$[0.25]$} \\
\hline \multirow[t]{2}{*}{ GPA of highest school certificate } & & $-0.89 * *$ & $-0.90 * *$ & $-0.90 * *$ & & \\
\hline & & [0.15] & {$[0.15]$} & [0.15] & & \\
\hline \multirow[t]{2}{*}{ in year 1} & & & & & $-1.01 * *$ & $-1.01 * *$ \\
\hline & & & & & [0.27] & [0.27] \\
\hline \multirow[t]{2}{*}{ in year 2} & & & & & $-1.05^{* *}$ & $-1.05^{* *}$ \\
\hline & & & & & [0.31] & [0.31] \\
\hline \multirow[t]{2}{*}{ in year 3-4 } & & & & & $-0.90 * *$ & $-0.90 * *$ \\
\hline & & & & & {$[0.30]$} & [0.30] \\
\hline \multirow[t]{2}{*}{ in year $5-8$} & & & & & -0.53 & -0.53 \\
\hline & & & & & {$[0.33]$} & {$[0.34]$} \\
\hline \multirow[t]{2}{*}{ Age at enrolment } & & & & -0.01 & & -0.00 \\
\hline & & & & {$[0.03]$} & & {$[0.03]$} \\
\hline Pathway 1 & & & ref. & ref. & ref. & ref. \\
\hline \multirow{2}{*}{ Pathway 2} & & & 0.14 & 0.15 & & \\
\hline & & & {$[0.30]$} & {$[0.32]$} & & \\
\hline in year $1-2$ & & & & & -0.05 & -0.03 \\
\hline & & & & & [0.39] & {$[0.40]$} \\
\hline in year 3-8 & & & & & 0.36 & 0.37 \\
\hline & & & & & {$[0.46]$} & {$[0.47]$} \\
\hline Pathway 3 & & & $0.73^{*}$ & $0.73^{*}$ & & \\
\hline & & & [0.29] & {$[0.29]$} & & \\
\hline in year $1-2$ & & & & & $0.72 *$ & $0.72 *$ \\
\hline & & & & & {$[0.36]$} & {$[0.36]$} \\
\hline in year 3-8 & & & & & 0.69 & 0.69 \\
\hline & & & & & {$[0.46]$} & {$[0.46]$} \\
\hline Pathway 4 & & & 0.01 & 0.02 & & \\
\hline & & & [0.29] & {$[0.30]$} & & \\
\hline in year 1-2 & & & & & -0.23 & -0.22 \\
\hline & & & & & {$[0.36]$} & {$[0.37]$} \\
\hline in year 3-8 & & & & & 0.30 & 0.31 \\
\hline & & & & & {$[0.40]$} & {$[0.41]$} \\
\hline
\end{tabular}

Notes. Standard errors in brackets. ${ }^{+} p<0.10,{ }^{*} p<0.05,{ }^{*} p<0.01$. Source: NEPS SC6; own calculations. Number of persons: 863; number of events (dropouts): 113.

Due to low numbers of events in each single time period, Models 5 and 6 include constraints for educational pathways indicating that the effect for the first year equals the effect for the second year and the effect for the third and fourth year equals the effect for the fifth to eighth year. 


\section{Endnotes}

${ }^{1}$ The "contrasting nature" (Mayer et al., 2007) between universities and universities of applied sciences might have converged to some degree due to the restructuring of study programmes decided in Bologna in 1997. In this article, however, we still concentrate mainly on study programmes heading towards the traditional degrees, because only a small portion of the present sample is already subject to this recent development.

${ }^{2}$ Even when we control for pre-tertiary pathways but not for the grade-point average of the highest school certificate, the effect of parental education is still significant on a 10 per cent level.

${ }^{3}$ The literature shows that the choice of fields of study relates to social origins (e.g. Ayalon \& Yogev, 2005). There is also evidence that dropout depends on the field of study (Heublein, Hutzsch \& Schreiber, 2010). Moreover, educational pathways might be connected to certain fields of study, making fields of study a potential mediator in the relationship between social origins, educational pathways, and dropout. Unfortunately, our data do not allow us to include fields of study as a time-varying covariate, because interviewers were asked to record only the last major in respondents who changed their field of study. In order to test for robustness, however, we include groups of study fields as time-constant variables. The effects of social origins and educational pathways do not change when the fields of study are included as covariates (see Tables A5 and A6 in the supplementary material). 